
MANAGEMENT AND ACCOUNTING

Fakultas Ekonomi Universitas Andi Djemma

Jl. Puang H. Daud No 4 Kota Palopo, Email: jemma.unanda@gmail.com

\title{
PENGARUH PENYALURAN KREDIT UMKM TERHADAP PENDAPATAN ANGGOTA PADA KOPERASI SIMPAN PINJAM BERKAT CABANG PALOPO
}

\author{
Penulis \\ ${ }^{1}$ Erniyati Caronge \\ ${ }^{1}$ Prodi Manajemen FE. Unanda \\ Email : ernicaronge@gmail.com
}

Info Artikel

p-ISSN : 2615-1871

e-ISSN : $2615-5850$

Volume 2 Nomor 2, September 2019

Received 26th July 2019 / Accepted 3th September 2019

\begin{abstract}
ABSTRAK
Koperasi simpan pinjam Berkat cabang Palopo merupakan usaha yang bergerak di bidang jasa keuangan dengan meyalurkan kredit kepada masyarakat. Dalam penelitian ini sampel penelitian berjumlah 23 orang anggota dari koperasi Simpan Pinjam Berkat Cabang Palopo. Untuk mencari hubungan antara variabel penyaluran kredit UMKM terhadap pendapatan Anggota, dengan metode analisis data yang digunakan adalah uji validitas dan reliabilitas, kemudian data dianalisis menggunakan regresi linier sederhana, uji $T$ (parsial) dan uji koefisien determinasi. Hasil dari penelitian ini menunjukkan nilai regresi linier sederhana adalah $\mathrm{Y}=20,516+0,431 \mathrm{X}$ $+e$, yang artinya apabila penyaluran kredit modal kerja UMKM mengalami peningkatan setiap pointnya, maka tingkat pendapatan anggotaakan megalami peningkatan sebesar 0,431 point. Sedangkan nilai korelasi Uji $T$ menunjukkan nilai signifikansi $0,003<0,005$, maka terdapat hubungan yang signifikan penyaluran kredit UMKM terhadap pendapatan anggota dan nilai koefisien determinasi ( $R$ square) menunjukkan bahwa persentase pemberian pemyaluran kredit mempunyai pengaruh yang positif terhadap terhadap tingkat pendapatan anggota sebesar $34,1 \%$, sedangkan sisanya $65,9 \%$ dipengaruhi oleh faktor-faktor lain yang tidak dibahas dalam penilitian ini.
\end{abstract}

Kata Kunci: Penyaluran Kredit, UMKM, dan Pendapatan Anggota.

\section{PENDAHULUAN}

Tujuan Pembangunan Nasional adalah terciptanya masyarakat adil dan makmur, material dan spiritual berdasarkan Pancasila dan UUD 1945. Diharapkan kemakmuran dan kesejahteraan dapat merata dan dinikmati oleh segenap rakyat Indonesia. Untuk mencapai tujuan tersebut, salah satu cara yang ditempuh oleh pemerintah adalah dengan meningkatkan pembangunan dibidang ekonomi sesuai dengan amanat pasal 33 UUD 1945. Maka diharapkan ketiga pelaku ekonomi di Indonesia yaitu: Badan Usaha Milik Negara, Badan Usaha Milik Swasta dan Koperasi dapat bekerjasama untuk mewujudkan kemakmuran dan kesejahteraan bersama.

Koperasi sebagai salah satu pelaku ekonomi Indonesia diharapkan dapat meningkatkan eksistensinya dan berperan lebih aktif dalam pembangunan. Hal ini sesuai dengan penjelasan pasal 33 UUD 1945 yang menyebutkan bahwa perekonomian disusun sebagai usaha bersama berdasar atas asas kekeluargaan. Dengan demikian bangun perekonomian yang sesuai diterapkan di Indonesia adalah koperasi.

Koperasi Simpan Pinjam (KSP) Berkat cabang palopo adalah salah satu lembaga ekonomi yang diharapkan dapat memperjuangkan kepentingan anggota dan meningkatkan kesejahteraan 
ekonomi anggota serta warga masyarakat di sekitarnya. Sebagai upaya untuk memperbaiki kondisi ekonomi demi meningkatkan taraf hidup dan kesejahteraan anggota. Berkembangnya koperasi akan dapat meningkatkan taraf hidup dan kemakmuran masyarakat sebagai anggota sehingga tujuan pembangunan Nasional dapat terwujud lewat koperasi. Bidang perkreditan (simpan-pinjam) salah satu usaha yang dikembangkan oleh Koperasi Simpan Pinjam (KSP) Berkat Cabang Palopo untuk meningkatkan kesejahteraan anggota, yaitu memberikan kredit yang bertujuan untuk menambah modal usahanya sehingga anggota tidak kesulitan dalam mencari modal.

Sehubungan dengan penyaluran kredit yang diberikan oleh Koperasi Simpan Pinjam (KSP) Berkat cabang Palopo dari tahun ke tahun kepada para anggotanya khususnya kepada UMKM dengan tujuan agar dapat meningkatkan kesejahteraan anggota, maka kredit yang di salurkan ini terus meningkat hal ini dapat terlihat pada tabel.

Tabel 1. Jumlah Penyaluran Kredit Koperasi Simpan Pinjam Berkat Cabang Palopo periode 2012-2016

\begin{tabular}{|c|c|}
\hline Tahun & Jumlah Kredit Yang Disalurkan \\
\hline 2012 & $\operatorname{Rp~} 5.063 .325 .000$ \\
\hline 2013 & $\operatorname{Rp~} 6.438 .850 .000$ \\
\hline 2014 & $\operatorname{Rp~} 7.261 .425 .000$ \\
\hline 2015 & $\mathrm{Rp} 8.873 .628 .000$ \\
\hline 2016 & $\mathrm{Rp} 9.307 .100 .000$ \\
\hline
\end{tabular}

Sumber: Data Koperasi Simpan Pinjam Berkat Cabang Palopo, 2017

Dengan melihat tabel penyaluran kredit pada koperasi Simpan Pinjam (KSP) Berkat cabang Palopo yang terus meningkat tiap tahunnya, maka dapat disimpulkan bahwa permintaan akan dana kredit (dana eksternal) sangatlah dibutuhkan bagi para anggota dari Koperasi Simpan Pinjam Berkat cabang Palopo, baik untuk kebutuhan menambah modal usaha ataupun untuk kebutuhan yang lain. Meningkatnya permintaan akan dana kredit diharapkan dapat sejalan dengan meningkatkan pertumbuhan pendapatan para anggota khususanya kepada UMKM penerima kredit dari Koperasi Simpan Pinjam (KSP) Berkat cabang Palopo, sehingga dapat sesuai dengan tujuan yaitu dapat meningkatkan kesajahteraan hidup anggota. Melihat fenomena di lapangan berkaitan dengan penyaluran kredit terhadap pendapatan berdasarkan hasil wawancara awal, maka dapat dilihat bahwa terjadi penurunan pendapatan dari anggota Koperasi Simpan Pinjam (KSP) Berkat cabang Palopo yang terlihat pada tabel berikut

Tabel 2. Jumlah kredit dan pendapatan anggota Koperasi Simpan Pinjam Berkat cabang Palopo sebelum dan sesudah menerima kredit

\begin{tabular}{|c|l|c|c|c|}
\hline No & Jenis usaha & $\begin{array}{c}\text { Jumlah kredit } \\
\text { yang disalurkan } \\
\mathbf{( R p )}\end{array}$ & $\begin{array}{c}\text { Pendapatan } \\
\text { sebelum menerima } \\
\text { kredit (Rp/Tahun) }\end{array}$ & $\begin{array}{c}\text { Jumlah pendapatan } \\
\text { sesudah menerima } \\
\text { kredit (Rp/Tahun) }\end{array}$ \\
\hline 1 & Bengkel las & 30.000 .000 & 150.000 .000 & 180.000 .000 \\
\hline 2 & Warung makan & 20.000 .000 & 110.000 .000 & 160.000 .000 \\
\hline 3 & Tukang ojek & 10.000 .000 & 37.000 .000 & 34.000 .000 \\
\hline 4 & Barang campuran & 15.000 .000 & 40.000 .000 & 38.000 .000 \\
\hline 5 & Penjual baju & 25.000 .000 & 140.000 .000 & 155.000 .000 \\
\hline
\end{tabular}

Sumber: Data Wawancara Anggota KSP Berkat Cabang Palopo, 2017 
Berdasarkan wawancara awal yang terlihat pada Tabel 2 terlihat bahwa jumlah pendapatan anggota Koperasi Simpan Pinjam (KSP) Berkat cabang Palopo ada yang mengalami penurunan jumlah pendapatan setelah mendapatkan bantuan kredit. Hal ini terjadi diakibatkan karena modal yang didapat dari kreditnya tersebut tidak sepenuhnya digunakan untuk modal usaha. Melihat situasi tersebut maka hal ini tidaklah sesuai dengan teori dari Kasmir dan Mubiyanto dalam Purnamayanti Dkk (2014) yang menyatakan bahwa kredit secara positif dapat meningkatkan pendapatan, karena pemberian kredit dapat menambah modal usaha.

Berdasarkan permasalahan yang dikemukakan, maka penulis tertarik untuk meneliti dan mengkaji permasalahan yang ada dan membahas permasalahan tersebut dalam bentuk uraian ilmiah yang berjudul Pengaruh Penyaluran Kredit UMKM Terhadap Pendapatan Anggota Pada Koperasi Simpan Pinjam Berkat Cabang Palopo. Tujuan dari penelitian ini adalah untuk mengetahui pengaruh penyaluran kredit UMKM terhadap pendapatan anggota pada Koperasi Simpan Pinjam Berkat Cabang Palopo.

\section{METODE PENELITIAN}

Untuk memperoleh data yang akurat yang dapat dipercaya kebenarannya dan relevan dengan masalah yang diteliti, maka pengumpulan data dilakukan dengan beberapa metode yaitu observasi, wawancara, kuesioner, dan dokumentasi. Populasi dari penelitian ini adalah anggota Koperasi Simpan Pinjam Berkat cabang Palopo yang berjumlah 23 orang. Teknik penentuan sampel dalam penelitian ini adalah sampling Jenuh yaitu teknik penentuan sampel apabila semua anggota populasi digunakan sebagai sampel. Hal ini sering dilakukan bila jumlah populasi relatif kecil, kurang dari 30 orang maka, semua anggota populasi dijadikan sampel yaitu berjumlah 23 orang. Metode analisis data yaitu meliputi analisis deskriptif, Uji Validitas dan Reliabilitas, Analisis Regresi Linier Sederhana, pengujian hipotesis melaui uji Uji T (Parsial) dan analisis Determinasi $\left(R^{2}\right)$.

\section{Hasil DAN PEMBAHASAN}

\section{Analisis Statistik Deskriptif}

a. Analisis Karakteristik Responden

Tabel 3. Karakteristik Responden Berdasarkan Jumlah Pendapatan/Tahun

\begin{tabular}{|c|c|c|c|}
\hline No & Tingkat Pendapatan/Tahun & Frekuensi & Persentase (\%) \\
\hline 1 & $\leq 10.000 .000,00$ & 0 & 0 \\
\hline 2 & $10.000 .000,00 \mathrm{~s} / \mathrm{d} 40.000 .000,00$ & 4 & 17,4 \\
\hline 3 & $40.000 .000,00 \mathrm{~s} / \mathrm{d} 70.000 .000,00$ & 11 & 47,8 \\
\hline 4 & $70.000 .000,00 \mathrm{~s} / \mathrm{d} 100.000 .000,00$ & 5 & 21,7 \\
\hline 5 & $\geq 100.000 .000,00$ & 3 & 13,0 \\
\hline & Total & 23 & 100 \\
\hline
\end{tabular}

\section{Sumber: Data Primer Setelah Diolah 2018}

Tabel 3. merepresentasikan karakteristik responden berdasarkan jumlah pendapatan/tahun yang terdapat di KSP Berkat Cabang Palopo dilihat dari frekuensi terbanyak yaitu 11 dengan persentase 47,8\%. Dengan demikian mayoritas responden adalah responden dengan pendapatan 40.000.000,00 s/d 70.000.000,00/tahun.

b. Hasil Analisis Deskriptif Variabel Penelitian 
berdasarkan masing-masing variabel dalam penelitian yaitu variabel penyaluran kredit $(\mathrm{X})$ dan variabel pendapatan anggota (Y). Dimana dari kuesioner yang disebar kepada 23 responden yang dijadikan sebagai sampel penelitian dengan jumlah 15 item pertanyaan variabel penyaluran kredit pada 5 indikator. Sedangkan, pada variabel pendapatan anggota terdiri dari 4 indikator dengan jumlah 12 item pertanyaan dan masingmasing indikator variabel terdiri dari 3 item pertanyaan yang diukur dengan 5 skala likert.

1) Tabel 4. Variabel Penyaluran Kredit (X)

\begin{tabular}{|c|l|c|c|}
\hline No. & \multicolumn{1}{|c|}{ Indikator } & Rata-Rata Skor & Keterangan \\
\hline 1. & Character (Karakter) & 4,57 & Sangat Setuju \\
\hline 2. & Capacity (Kemampuan) & 4,27 & Sangat Setuju \\
\hline 3. & Capital (Modal) & 3,90 & Setuju \\
\hline 4. & Collateral (Jaminan) & 3,86 & Setuju \\
\hline 5. & $\begin{array}{l}\text { Condition of economy (Kondisi } \\
\text { Ekonomi) }\end{array}$ & 4,19 & Setuju \\
\hline
\end{tabular}

2) Tabel 5. Variabel Pendapatan Anggota (Y)

\begin{tabular}{|c|c|c|c|}
\hline No. & Indikator & Rata-Rata Skor & Keterangan \\
\hline 1. & Penjualan Kotor & 4,34 & Sangat Setuju \\
\hline 2. & Penjualan bersih & 4,21 & Sangat Setuju \\
\hline 3. & Pendapatan Bunga & 4,17 & Setuju \\
\hline 4. & Pendapatan Sewa & 3,08 & Kurang Setuju \\
\hline
\end{tabular}

\section{Hasil Uji Validitas dan Reliabilitas}

a. Hasil Uji Validitas

Berdasarkan uji validitas dari masing-masing variabel penyaluran kredit $(\mathrm{X})$ dan pendapatan (Y), dapat disimpulkan bahwa semua item pernyataan yang disebar kepada 23 responden yang dijadikan sebagai sampel maka, untuk masing-masing variabel dinyatakan valid. Hal ini dapat dilihat dari kriteria pengujian validitas dengan nilai skor total lebih dari 0,30 dengan tingkat signifikansi untuk setiap item pernyataan pada setiap variabel Penyaluran Kredit (X) dan Pendapatan Anggota (Y) nilainya lebih kecil dari sig 0,05 maka instrumen pernyataan dikatakan valid.

b. Hasil Uji Reliabilitas

Dari hasil uji reliabilitas semua variabel yang dijadikan instrumen dalam penelitian ini adalah reliabel atau handal karena menunjukkan tingkat reliabilitas yang tinggi yaitu variabel Penyaluran Kredit memiliki nilai Cronbach's Alpha 0,919 sedangkan, variabel Pendapatan Anggota nilai Cronbach's Alpha sebesar 0,893. Hal ini dibuktikan dengan nilai koefisien Alpha lebih besar dari 0,60 sehingga dapat digunakan sebagai alat ukur yang handal atau dapat dipercaya.

\section{Hasil Uji Analisis Regresi Linier Sederhana}

Uji regresi bertujuan untuk mengetahui ada tidaknya pengaruh variabel independen terhadap variabel dependen. Adapun variabel independen adalah Penyaluran Kredit (X) dan variabel dependen yaitu Pendapatan Anggota (Y) dengan hasil pengolahan data dapat dilihat 
pada tabel.

Tabel 6. Uji Regresi Linier Sederhana

Coefficients $^{a}$

\begin{tabular}{|c|c|c|c|c|c|}
\hline \multirow[b]{2}{*}{ Model } & \multicolumn{2}{|c|}{ Unstandardized Coefficients } & $\begin{array}{c}\text { Standardized } \\
\text { Coefficients }\end{array}$ & \multirow[b]{2}{*}{$t$} & \multirow[b]{2}{*}{ Sig. } \\
\hline & $B$ & Std. Error & Beta & & \\
\hline $\begin{array}{ll}1 & \text { (Constant) } \\
& \text { Penyaluran Kredit }\end{array}$ & $\begin{array}{r}20.516 \\
.431\end{array}$ & $\begin{array}{r}8.264 \\
.131\end{array}$ & .584 & $\begin{array}{l}2.483 \\
3.294\end{array}$ & $\begin{array}{l}.022 \\
.003\end{array}$ \\
\hline
\end{tabular}

a. Dependent Variable: Pendapatan anggota

Sumber: Data Diolah, 2018 melalui SPSS version 23

Dari tabel 6 uji regresi linier sederhana diperoleh persemaan regresi sebagai berikut:

$$
\mathrm{Y}=20,516+0,431 \mathrm{X}+e
$$

Dari persamaan di atas, dapat diartikan bahwa dengan konstanta (a) adalah sebesar 20,516 hal ini berarti jika tidak ada perubahan variabel penyaluran kredit $(\mathrm{X})$, maka besarnya variabel pendapatan anggota (Y) sebesar 20,516. Nilai koefisien penyaluran kredit sebesar 0,431 berpengaruh positif terhadap peningkatan pendapatan anggota. Hal ini menunjukkan bahwa setiap perubahan penyaluran kredit mengalami kenaikan satu satuan maka variabel pendapatan anggota meningkat sebesar 0,431 dengan asumsi bahwa variabel independen yang lain tetap.

a. Hasil Uji T (Parsial)

Hasil pengujian antara variabel independen terhadap variabel dependen secara individu (parsial) yang dilakukan dengan uji t adalah Hipotesis pertama dapat dilihat pada tabel 17, variabel penyaluran kredit mempunyai tingkat signifikansi sebesar 0,003. Hal ini berarti menerima $\mathrm{H}_{\mathrm{a}}$ sehingga dapat dikatakan bahwa penyaluran kredit berpengaruh terhadap pendapatan anggota karena tingkat signifikansi yang dimiliki variabel penyaluran kredit lebih kecil dari 0,05 .

b. Uji Analisis Determinasi $\left(\mathrm{R}^{2}\right)$

Koefisien determinasi digunakan untuk mengetehui seberapa jauh variabel- variabel bebas dalam menerangkan variabel terikatnya. Nilai koefisien determinasi terletak antara 0 sampai dengan $1\left(0 \leq R^{2} \leq 1\right)$. Nilai koefisien determinasi ditentukan dengan melihat nilai $R$ square sebagaimana dapat dilihat pada Tabel.

Tabel 7. Hasil uji analisis determinasi

Model Summary

\begin{tabular}{|l|r|r|r|r|}
\hline Model & \multicolumn{1}{|c|}{$R$} & R Square & Adjusted R Square & $\begin{array}{c}\text { Std. Error of the } \\
\text { Estimate }\end{array}$ \\
\hline 1 & $.584^{\mathrm{a}}$ & .341 & .309 & 5.46064 \\
\hline
\end{tabular}

a. Predictors: (Constant), Penyaluran Kredit

Sumber: Data Diolah, 2018 melalui SPSS version 23

Hasil perhitungan regresi dapat diketahui bahwa nilai koefisien determinasi ( $R$ square) yang diperoleh sebesar 0,341 atau $34,1 \%$. Hal ini berarti bahwa variabel dependen yaitu pendapatan anggota dipengaruhi oleh variabel independen yaitu penyaluran kredit, adalah sebesar $34,1 \%$. Sedangkan sisanya $65,9 \%$ dipengaruhi oleh variabel lain yang tidak dimasukkan dalam pembahasan penelitian ini. 


\section{Pembahasan}

Hasil pengujian analisis statistik dalam penelitian ini menunjukkan adanya pengaruh antara kedua variabel yang diteliti yaitu variabel penyaluran kredit terhadap variabel pendapatan anggota pada Koperasi Simpan Pinjam Berkat Cabang Palopo. Dari hasil analisis regresi diperoleh angka yang menyatakan bahwa penyaluran kredit berpengaruh terhadap pendapatan yang dibuktikan oleh hasil perhitungan secara parsial dimana nilai $t_{\text {hitung }} \geq t_{\text {tabel }}$ yaitu dengan nilai 3,294 $\geq 2,080$. Jika $t_{\text {hitung }} \geq t_{\text {tab el }}$, maka $\mathrm{H}_{\mathrm{o}}$ ditolak dan $\mathrm{H}_{\mathrm{a}}$ diterima maka ada pengaruh antara variabel independen penyaluran kredit terhadap variabel dependen pendapatan anggota.

Dengan nilai signifikan sebesar $0,003<0,05$ dan hasil uji regresi linier sederhana menunjukkan nilai koefesien penyaluran kredit sebesar 0,431 yang artinya diperoleh hasil bahwa variabel penyaluran kredit berpengaruh positif terhadap pendapatan anggota. Hasil regresi juga menunjukkan nilai koefisien determinasi sebesar 0,341 atau 34,1\% yang artinya bahwa sumbangan pengaruh variabel penyaluran kredit terhadap pendapatan anggota yaitu sebesar 34,1\% Sedangkan, sisanya 65,9\% dipengaruhi oleh variabel lain yang tidak dimasukkan dalam pembahasan penelitian ini.

Kredit yang diberikan oleh Koperasi Simpan Pinjam Berkat Cabang Palopo kepada anggota diharapkan dapat digunakan untuk meningkatkan atau mengembangkan usahanya, yang berarti dapat meningkatkan keuntungan yang akan mereka peroleh. Hal ini akan berpengaruh terhadap peningkatan pendapatan. Dengan meningkatnya pendapatan anggota maka pendapatan Koperasi akan terus meningkat, apabila anggota koperasi terus memanfaatkan kredit tersebut untuk pengembangan usahanya. Anggota koperasi dapat menikmati kredit untuk memperbesar usahanya, baik untuk meningkatkan produksi, perdagangan maupun untuk memulai usaha baru.pada dasarnya kredit bertujuan untuk dapat manigkatkan produktivitas anggota secara menyeluruh.

Penggunaan dana kredit yang tidak tepat (tidak pruduktif) dapat mengakibatkan kerugian yang sangat besar bagi penerima kredit. Disamping mereka mengalami kerugian dalam usahanya, mereka juga harus menanggung pengembalian dana tersebut. Untuk dapat memanfaatkan dana kredit secara efektif dan efisien maka penerima kredit harus dapat memilih jenis produksi barang atau jasa yang tepat dalam usahanya. Dari data yang diperoleh dalam penelitian melalui angket dan wawancara terhadap responden yang dijadikan sampel menunjukkan bahwa sebagian besar anggota koperasi Berkat Cabang Palopo yang mengambil kredit atas inisiatif sendiri. Adanya inisiatif sendiri dari anggota menunjukkan bahwa anggota mempunyai pandangan yang positif terhadap kredit yang diberikan oleh Koperasi Berkat Cabang Palopo, sehingga mereka mengambil kredit untuk menambah modal dengan harapan dapat mengembangkan usahanya yang akhirnya akan meningkatkan pendapatannya.

Prosedur peminjaman kredit di Koperasi Berkat Cabang Palopo yang mudah, bunga ringan dan lokasi yang dekat dengan tempat tinggal anggota, sehingga dapat mendorong anggota dan masyarakat palopo lebih memilih megambil kredit di Koperasi Berkat Cabang Palopo. Hal inilah yang menjadi kelebihan KSP Berkat dalam melayani anggota untuk penyaluran kredit dan tidak semata - mata hanya bertujuan komersil saja, namun bersifat membantu permodalan usaha anggota.

Dengan demikian berdasarkan hipotesis yang diajukan dalam penelitian ini dan dengan hasil pengujian data pada hipotesis kerja atau dengan kata lain Ha diterima yang berarti ada pengaruh positif dan signifikan antara Penyaluran Kredit terhadap Pendapatan Anggota pada 
Koperasi Simpan Pinjam Berkat Cabang Palopo dan dari hasil penelitian ini juga dapat dibandingkan dengan salah satu penelitian terdahulu yang dilakukan oleh Jati (2015) yang menyimpulkan bahwa dari hasil penelitiannya penyaluran kredit berpengaruh positif dan signifikan terhadap pendapatan anggota sehingga, hasil penelitian yang diperoleh adalah sama dengan hasil penelitian yang dilakukan. Hal ini juga sesuai dan sejalan dengan teori dari Kasmir dan Mubiyanto dalam Purnamayanti Dkk (2014) yang menyatakan bahwa kredit secara positif dapat meningkatkan pendapatan, karena pemberian kredit dapat menambah modal usaha.

\section{SIMPULAN DAN SARAN}

\section{Simpulan}

Berdasarkan pembahasan hasil analisis penelitian yang telah dilakukan maka Ada pengaruh positif dan signifikan antara penyaluran kredit UMKM terhadap pendapatan Anggota pada Koperasi Simpan Pinjam Berkat Cabang Palopo yang ditunjukkan dari hasil uji T (parsial) dengan memperoleh nilai $t_{\text {hitung }}=3,294$ dengan signifikansi $0,003<0,05$. Besarnya sumbangan pengaruh penyaluran kredit terhadap pendapatan anggota pada Koperasi Simpan Pinjam Berkat Cabang Palopo Tahun 2018 adalah sebesar 0,341 atau 34,1\% sedangkan sisanya 65,9\% dipengaruhi oleh faktor lain yang tidak diungkap dalam penelitian ini.

\section{Saran}

Berdasarkan simpulan tersebut diatas, maka saran yang dapat diberikan antara lain :

1. Adanya pengaruh penyaluran kredit yang diberikan terhadap peningkatan pendapatan anggota tersebut hendaknya dapat dijadikan bahan pertimbangan bagi KSP Berkat untuk dapat lebih meningkatkan kredit yang diberikan sesuai dengan kebutuhan anggota (peminjam) dengan masih tetap berpegang pada asas kekeluargaan dan prinsip kehatianhatian dalam pemberian kredit.

2. Pemberian kredit hendaknya lebih tepat sasaran, dengan memberikan pinjaman kredit/modal yang sesuai dengan kebutuhan anggota dalam mengembangkan usahanya dengan melihat sisi prosedur penyaluran kredit yaitu memberikan jaminan yang dirasa masih memberatkan sebagian anggota. Dalam meningkatkan pendapatannya anggota koperasi juga harus lebih meningkatkan pendapatannya dari sisi pendapatan sewa sehingga pendapatan yang diperoleh lebih meningkat lagi.

\section{DAFTAR PUSTAKA}

Anoraga, P. dan N. Widiyanti. 2007. Dinamika Koperasi. Jakarta: PT. Rineka cipta.

Boediono. 2002. Ekonomi Mikro. Yogyakarta: BPFE.

Budianto, Nanang. 2005. Pengaruh Pemberian Kredit Produksi Terhadap Pendapatan Anggota Koperasi Banjar Artha Sarana (Bathara) Di Kabupaten Banjarnegara [Skripsi]. Semarang (ID): Universitas Negeri Semarang.

Dahlan, Siamat. 2005. Manajemen Lembaga Keuangan: Kebijakan Moneter dan Perbankan, edisi kesatu. Jakarta: Fakultas Ekonomi Universitas Indonesia.

Fahmi, Irham dan Larasati Hadi Yovi. 2010. Pengantar Manajemen Perkreditan. Bandung: Alfabeta.

Firdaus, Rachmat dan Maya Ariyanti. 2004. Manajemen Perkreditan Bank Umum: Teori, Masalah, Kebijakan dan Aplikasinya Lengkap dengan Analisis Kredit. Bandung: Alfabeta.

Fitriyanto, Eka. 2015. Pengaruh Persepsi Pelaku UMKM Mengenai Kredit Usaha Rakyat 
(KUR) Terhadap Modal Kerja dan Nilai Produk Usaha Di Kabupaten Wonosobo [Skripsi]. Yogyakarta (ID): Universitas Negeri Yogyakarta.

Harahap, Sofyan Syafri. 2002. Analisa Kritis Atas Laporan Keuangan. Jakarta: PT Raja Grfindo Persada.

Hasibuan, Malayu S. P. 2015. Dasar-dasar Perbankan. Jakarta: Bumi Aksara.

Hendar dan Kusnadi. (2002). Ekonomi Koperasi Untuk Perguruan Tinggi. Jakarta: FEUI.

Ismail. 2010. Manajemen Perbankan. Edisi Pertama. Jakarta: Kencana.

Jati, Dica Suci Enggar. 2015. Pengaruh Pemberian Kredit Modal Kerja Terhadap Tingkat Pendapatan Usaha Kecil dan Menengah (UKM) PT. Bank Pembiayaan Rakyat Syari'ah (BPRS) Margirizki Bahagia Bantul [Skripsi]. Yogyakarta (ID): Universitas Negeri Sunan Kalijaga.

Jusup, A. 2005. Dasar-dasar Akuntansi. Yogyakarta: STIE YKPM.

Kasmir. 2005. Dasar-Dasar Perbankan. Jakarta: PT. Raja Grafindo Persada.

Kusnadi. 2000. Akuntansi Keuangan Menengah. Malang: Universitas Brawijaya.

Mulyono, Teguh Pudjo. 2007. Manajemen Perkreditan Bagi Perbankan Komersil. Yogyakata: BFFE.

Rahardja, P. dan M, Manurung. 2002. Teori Ekonomi Mikro. Jakarta: FEUI.

Riduwan. 2003. Skala Pengukuran Variabel-Variabel Penelitian. Bandung: CV Alfabeta.

Rivai, H.Veithzal. 2013. Buku Commercial Bank Management: Manajemen Perbankan Dari Teori Ke Praktik. Edisi 1. Cetakan Ke-2. Jakarta: Rajawali Pers.

Soesilo. 2008. Permodalan dan Perkreditan Koperasi. Yogyakarta: Kanisius.

Sugiyono. 2011. Metode Penelitian Kuantitatif Kualitatif dan R\&D. Bandung: Alfabeta.

Suhardjono. 2003. Manajemen Perkreditan: Usaha Kecil dan Menengah. Yogyakarta: AMP YKPN.

Sukirno, Sadono. 2002. Pengantar Teori Mikro Ekonomi. Jakarta: Raja Grafindo Persada.

Suyatno, Thomas dkk. 2007, Dasar-dasar Perkreditan. Jakarta: PT. Gramedia Pustaka Utama.

Tohar, M. 2004. Permodalan dan Perkreditan Koperasi. Yogyakarta: Kanisius.

Purnamayanti, Ni Wayan Ana, dkk. 2014. Pengaruh Pemberian Kredit dan Modal Terhadap Pendapatan UKM. E-Journal Ilmu Manajemen. 3 (2):2-4 